\title{
Employee Skills, Management Style and Organizational Culture in Implementation of Strategic Plans in Middle Level Colleges in Thika Sub-County, Kenya
}

\author{
George K. Mwangi ${ }^{1}$, Julius O. Olayo ${ }^{1} \&$ Alice N. Simuyu ${ }^{2}$ \\ ${ }^{1}$ Department of Human Resource Management, Jomo Kenyatta University of Agriculture and Technology, \\ Kenya \\ ${ }^{2}$ Department of Human Resource Management, Karatina University, Kenya \\ Correspondence: George K. Mwangi, Department of Human Resource Management, Jomo Kenyatta University \\ of Agriculture and Technology, Kenya. Tel: 254-724-799-967. E-mail: gmwanngi@yahoo.com
}

Received: March 9, 2015

Accepted: May 25, 2015

Online Published: May 22, 2015

doi:10.5539/ijbm.v10n6p199

URL: http://dx.doi.org/10.5539/ijbm.v10n6p199

\begin{abstract}
This study sought to investigate the extent of employee skills, management styles and organizational culture on strategic plans implementation in middle level colleges in Kenya. The study involved 40 middle level colleges located within Thika sub-county, Kiambu County. The study adopted descriptive study design. The study population comprised of 400 personnel working in middle level colleges. A sample of 100 respondents was selected using simple random sampling in order to obtain data using questionnaires. The data collected were analysed using SPSS. The study revealed that the employees' skills and management style are vital in the strategic plans implementation. The results further revealed that the staff in the various units in the organizations had the proper skills to ensure the smooth implementation of strategic plans. Further, the findings indicated that the management offers support for the implementation of new strategic plans and that the organizational culture inhibits the introduction of new strategic plans implementation. This study is important in that it will guide the management of various middle level colleges in drafting and implementing strategic plans.
\end{abstract}

Keywords: strategy implementation, Kenya, culture, management style, skills, culture

\section{Introduction}

Strategic plan is an important component of strategic management (Borg \& Gall, 2006). Strategy implementation remains the biggest challenge in strategic management. It is well documented during the last decades that strategy implementation often fails (Arthur, 1992; Hrebiniak, 2006, Aalto University, 2000-2011). In practice, strategy usually remains a top management issue even though employees are the ones implementing the strategy (Mantere \& Vaara, 2008; Whittington, 2007). People do not understand their role as part of the strategy. Employees lack knowledge and skills while managers may have the prerequisite management skills to support the implementation of strategic plans (Wooldridge et al., 2008; Pfeffer \& Sutton, 2000).

According to YuklandLepsinger (2007) knowledge is the most strategically important resource to an organization. It is created and held by individuals not organization (Huse, 2000). To become a leading-edge organization, any middle-level college will need to be more concerned with the types of programmes they use to improve workplace learning and performance, not simply how much money they use on training. Organizations must invest in the continual learning of workers in order to remain competitive (Bernardin, 2007;Boxall\& Purcell, 2000). Following introduction of strategic plans, it is imperative for the middle level colleges to re-assesses the knowledge and skills of the work force and where there are gaps, avenues for training be created (Keuning, 2008). This will improve the level of achievement of the plans because the employees will have the right skills for the right jobs.

The role of management of the middle level colleges is key to successful implementation of plans (Schuster, 2002). It sets the pace in the implementation process. Following the conflicting perception of management as rational, science-based process or intuitive, Burnes tried to look at it more holistically (Burnes, 2004). He identified three distinct levels of management: philosophical (goal formation), scientific (goal accomplishment and evaluation) and as an art (implementation of decisions). Implementation of strategic plans is an art because 
there appears to be a particular talent necessary to persuade others that plans should be accepted (Drucker, 2005). The manager must possess negotiation skills to convince other employees the need to change and to support strategy implementation. Due to the conflicting perceptions to change by employees, Cowling (2009) exalts the elements of democratic management. In all middle level colleges, this is very important if strategic plans are to be well implemented.

Managers and employees do not perform their duties in a value-free vacuum. Rather, their work and the way it is done is governed, directed and tempered by an organizations culture particularly values, beliefs, customs and systems unique to that culture. Culture is viewed by the contemporary authors as complex organizational phenomena (Schein, 2010; Kotter \& Heskett 1992) that is formed as a continuous sequence (Denison \& Mishra, 1995). Richard and Bagozzi (2003) acknowledges that internal orientation of employees is based primarily on the culture, beliefs, ethics and assumptions of the organizational staff, and therefore has the potential to be one of the most powerful influences on strategic management. Given, culture is not static, but it changes with time. However, given that culture is locked into beliefs, values and norms of each individual in the organization, and because these are difficult constructs to alter, cultural change is usually slow (Burnes, 2006).

As middle level colleges implement strategic plans that require culture change, management must be alive to the fact that they need to look for ways to encourage staff to adjust their values and beliefs (Keuning, 2008). Culture does not spring up automatically, but a product of a number of influences: the ambient society's values and characteristics, the organization's history and past leadership, and factors such as industry and technology (Odiek, 2010). Strategic plan implementation may involve a change in the organizational culture (Akhtar et al., 2008). It is therefore incumbent on the manager during strategy implementation to come up with ways of addressing issues of organizational culture lest they impede on the implementation process. It is also important to adopt common themes that shape the organization culture towards desired strategy (Odiek, 2010). According to Glueck (2000), the organization culture is at the centre of the success of implementation of strategic plans. There is a need for middle level colleges in Kenya to gain understanding of the organizational culture existing in the institution (Carney, 2004; Wright et al., 2005).

The value of middle level colleges in the education concept of Kenya as a nation cannot be underestimated. These colleges act as an absorbent factor that helps regulate the steadily increasing dynamic nature of students clearing the secondary level of education. This is important, consideration that the numbers of universities in the country are not in a position to handle all the students and not all individuals qualify for or can afford the cost associated with the universities. The purpose of the research was to understand the role of employee skills, management style and organizational culture in the implementation of strategic plans in middle level colleges in Kenya.

\section{Research Methodology}

\subsection{Sampling Design}

Descriptive design was used in this research. Descriptive survey is able to describe and explains the present status, situations, events and trends and allows an in depth collection of information (Mugenda \& Mugenda, 2003). The primary data was gathered in the field through sample survey method as described by Orodho (2003). A target population was selected as indicated by Mugenda (2008). Stratified sampling was used to divide the respondents into strata to ensure that respondents from the various strata were well represented. Simple random sampling was then used to select the sample size as it gave every member of the population an equal chance of being selected in the sample (Kothari, 2005). A sample size of 100 respondents was selected for data collection (Kothari, 2005). This was from a total population of 400 staff comprising of the management, teaching staff and non-teaching staff working in middle level colleges within Thika sub-county, as estimated from the District Education Office records for Thika sub-county. This represented 25 percent of the target population which was appropriate for descriptive studies (Mugenda \& Mugenda, 2003). A sample size for each target category is shown in Table 1. 
Table 1. The sample size selected for each category of target respondents

\begin{tabular}{llll}
\hline Category & Number of Respondents & Sample Percentage & Sample Size \\
\hline Lecturers & 188 & 0.25 & 47 \\
Management & 40 & 0.25 & 10 \\
Supervisors & 36 & 0.25 & 9 \\
Non-Teaching Staff & 136 & 0.25 & 34 \\
Total & $\mathbf{4 0 0}$ & $\mathbf{1 . 0}$ & $\mathbf{1 0 0}$ \\
\hline
\end{tabular}

\subsection{Data Collection Instruments and Procedures}

Data were collected by the use of self administered questionnaires as is less expensive, easier to administer to a large population and uniformity in measurement (Mugenda \& Mugenda, 2003). The questionnaire included both open and closed ended questions. The questionnaires were administered to the respondents on a "drop and pick" later technique as all respondents were literate. However; this was supplemented with personal interviews to clarify certain issues for both the respondent and the researcher.

\subsection{Data Analysis Techniques}

This study being descriptive survey design used simple descriptive statistics in the analysis of its data. According to Borg (2006), the commonly used methods in reporting descriptive surveys are frequency distributions, percentages and tabulations. The data collected were coded; classified and systematically analyzed. Data were analysed using Statistical Package for Social Sciences (SPSS) package. Descriptive statistics such as mean, mode, standard deviation and frequency distribution were used to analyze the data as proposed by Mugenda (2008).

\section{Research Results}

\subsection{Respondents' Characteristics}

Of the 100 college employees sampled, only 10 didn't return response. This is a high response rate to ensure that the results are representative of the population (Block, 2007). Of the total respondents, $66.67 \%$ of them were males while $33.33 \%$ were females. The figures represent a fair distribution of the respondents in relation to their gender. The study findings also indicated majority of the respondents were aged between 31-40 years while the smallest proportion was aged above 50 years (Figure 1). The findings indicated that the respondents were distributed in all the age groups.

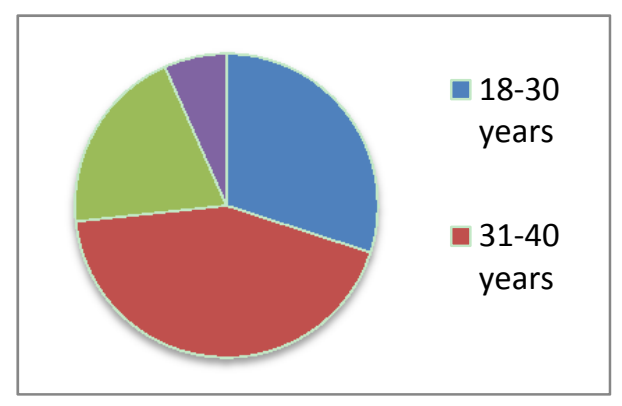

Figure 1. Percentage of the respondents by age

The study revealed that the respondents had high literacy levels as majority of the respondents had a university degree level (Figure 2). 


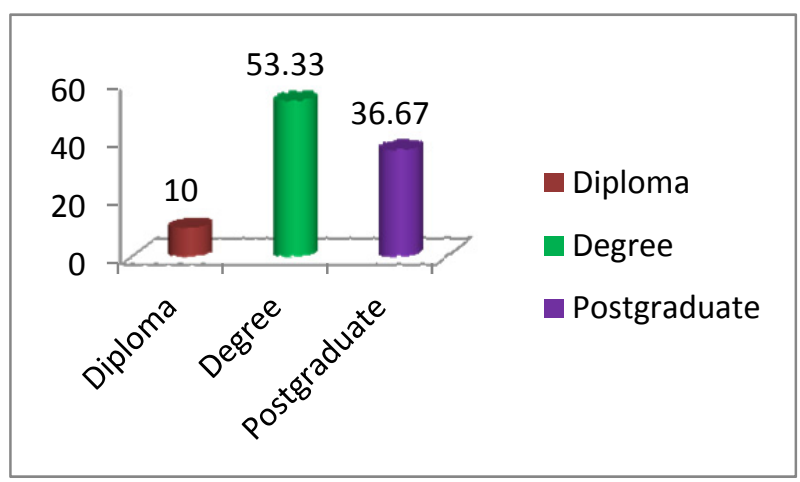

Figure 2. Percentage of respondents by education level

The research also revealed that majority of the respondents had a work experience of 4-6 years. The rest had varied work experiences (Figure 3). This meant that the respondents had enough understanding of the issues in the colleges.

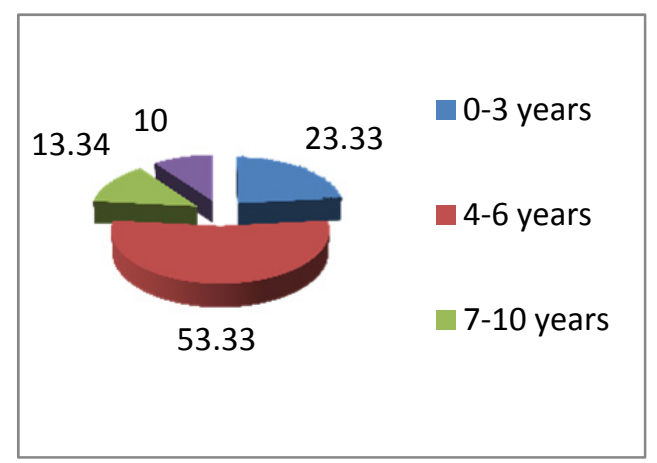

Figure 3. Percentage of respondents by work experiences

\subsection{Effects of Employees Skills in Implementation of Strategic Plans}

The researcher sought to establish how the individual employee's skills influenced implementation of strategies. The research findings indicated that a majority of the respondents were of the opinion that employees' skills are likely to influence the implementation of policies in the colleges (Figure 4). However, some disagreed while a small fraction seemed not decided (Figure 4).

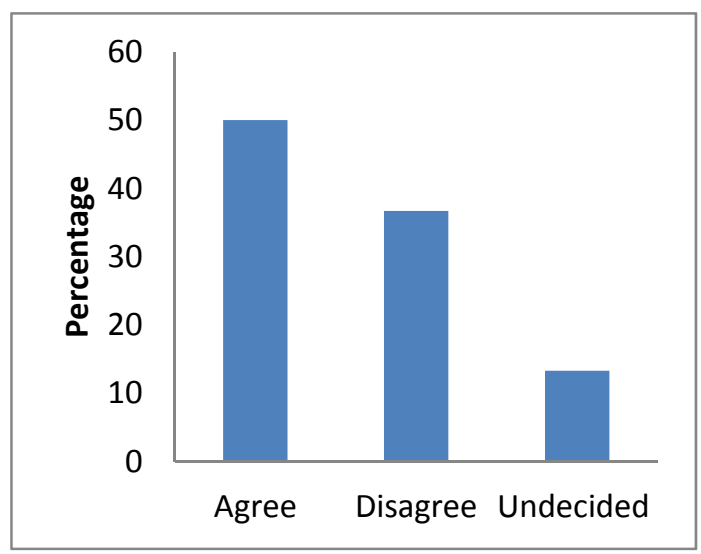

Figure 4. Whether employee's skills have effect on implementation of strategic plans

The research further revealed that, colleges trained the employees so as to update their skills in line with the 
strategies implementation. This was supported by $57.8 \%$ of the respondents while $30 \%$ felt that they were not adequately trained to update their skills. However, $12.2 \%$ were undecided.

From the study findings, it was established that the extent of effects of individual skills on implementation of strategic plans was $78.9 \%$ (Table 2). It also emerged that the extent of updating the employees' skills on implementation of strategic plans was also high (Table 2). This is a clear indication that employees' skills play a key role in the implementation of strategic plans and colleges update the skills of the employees regularly to ensure that they are relevant in output delivery.

Table 2. Extent of effects of individual skills on implementation of strategic plans

\begin{tabular}{llllllll}
\hline Effects of individual skills on implementation of strategic & A & D & U & Total & Mean & \% & S D \\
\hline Individual skills affects implementation of strategic plans & 45 & 33 & 12 & 90 & 2.367 & 78.9 & 0.710 \\
Employees skills are continually updated through training & 52 & 27 & 11 & 90 & 2.456 & 81.9 & 0.706 \\
\hline
\end{tabular}

\subsection{Effect of Management Style on Implementation of Strategic Plans}

The research also sought to establish the effect of management style on implementation of strategic plans. The research findings indicate that $73.3 \%$ of the respondents felt that the management style affected implementation of strategies. This meant that management style helps to promote employee enthusiasm about strategies and achievement of college's goals. A small proportion of the respondents $(6.67 \%)$ felt that the management style had no effect on implementation of strategies. However, $20 \%$ of the respondents were undecided.

The research findings indicated that a majority of the respondents were of the opinion that the management offers support which enhances the implementation of the strategies as supported by $63.3 \%$ of the respondents. While $30 \%$ felt that the management is not supportive enough to help strategies implementation. However $6.7 \%$ were undecided. The results are interpreted to mean the managers ensure the necessary resources are available to ensure effective implementation of strategies.

The study findings indicated that the extent of effect of management style on implementation of strategic plans was high to indicating that the colleges involved the employees in the implementation of strategic plans to a large extent (Table 3). It also emerged that the respondents agreed that the colleges were supportive of new strategic plans to a very high extent (Table 3). These findings bring out an element of employees involvement in the implementation of strategic plans in the colleges under study.

Table 3. Extent of effects of management style in strategic plans implementation

\begin{tabular}{lllllllll}
\hline Involvement of employees in the strategic plans implementation. & A & D & U & Total & Mean & Percent & S D \\
\hline Management style in colleges affects implementation of strategic plans & 66 & 6 & 18 & 90 & 2.533 & 84.4 & 0.8100 \\
The management in colleges is supportive in new strategic plans & 57 & 27 & 6 & 90 & 2.9 & 96.7 & 0.949 \\
\hline
\end{tabular}

Key: A-Agree $\quad$ D-Disagree $\quad$ U-Undecided $\quad$ SD - Standard Deviation.

\subsection{Effects of Colleges' Culture on Implementation of Strategic Plans}

The research sought to establish the effects of colleges' culture on implementation of strategic plans. Results revealed that $66.7 \%$ agreed with the assertion that college's culture affects implementation of strategic plans. However, $25.6 \%$ disagreed while $7.7 \%$ were undecided. The results indicated that culture change could help improve colleges' ability to implement strategic plans and goals. The research findings further indicated that colleges' culture inhibits introduction of new strategies as supported by majority of the respondents. A small proportion felt that colleges' culture was not an inhibiting factor in the implementation of new strategies or were undecided. This indicates that culture could lead to resistance of new strategies due to the fear of the unknown thus inhibiting implementation of new strategic plans. 


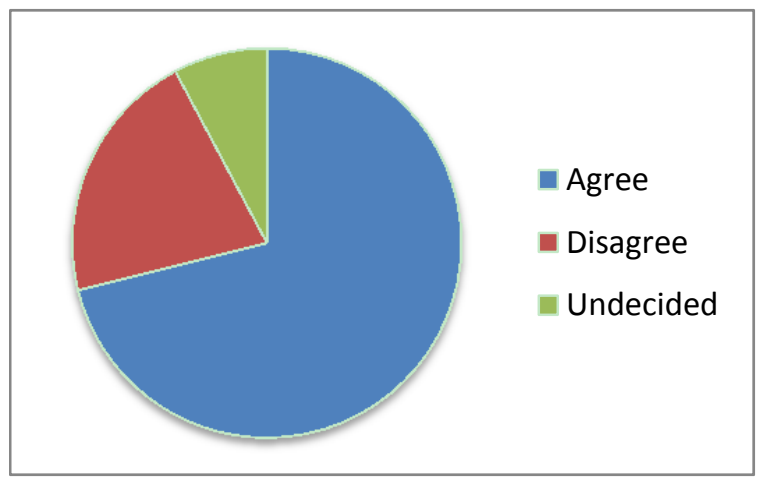

Figure 5.Respondents feeling that colleges' culture inhibits introduction of new strategic plans

The study revealed that the extent of effect of colleges' culture on implementation of strategic plans was very high (Table 4). This could mean that colleges' culture influence implementation of strategic plans to a larger extent. The study also revealed that the extent of colleges' culture inhibiting implementation of strategic plans was equally very high (Table 4). This could mean that colleges' culture inhibits implementation of strategic plans by influencing the support of other stakeholders.

Table 4. Extent of effects of colleges' culture on strategic plans implementation

\begin{tabular}{llllllll}
\hline Effects of colleges' culture on strategic plans implementation. & A & D & U & Total & Mean & \% & S D \\
\hline Colleges' culture affects implementation of strategic plans & 60 & 23 & 7 & 90 & 2.589 & 86.3 & 0.634 \\
The culture in colleges inhibits implementation of new strategic plans & 64 & 19 & 7 & 90 & 2.633 & 87.8 & 0.626 \\
\hline
\end{tabular}

Key: A-Agree D-Disagree U-Undecided SD - Standard Deviation.

Of the three factors analysed in this study, organization culture has the greatest impact on implementation of strategic plan (Figure 6). This was followed by management style and individual skills in that order (Figure 6).

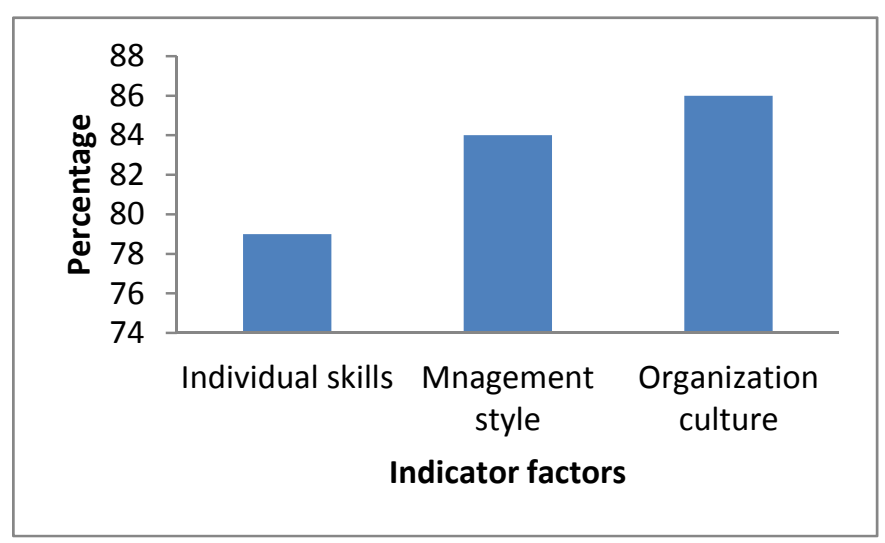

Figure 6. Extent of indicator factors on implementation of strategic plan

\section{Discussions}

The study had set out to determine the effect of individual employee's skills, management style and organization culture on the strategic plans implementation. The study established that the staff in the various units in the organizations had the proper skills to ensure the smooth implementation of policies as indicated by majority of the respondents. The respondents reported that the institutions are updating their skills through training to avoid redundancy. The respondents indicated that employee out-dated skills in the colleges are likely to inhibit the implementation of strategic plans. These findings of the study are considered relevant and in concordance with the study findings of Fulford (2005) and Shipton et al. (2005) who pointed out that the colleges that have 
empowered its employees with skills to perform their duties have realised tremendous growth in the achievement of their college objectives and accomplishment of its mission. Fulford (2005) suggests that the colleges should empower its employees with knowledge and skills by initiating training programs so as to enhance the performance of the colleges.

The study also sought to establish the effects of management style on implementation of strategic plans. The research findings indicated that a majority of the respondents were of the opinion that the management offers support which affects the implementation of strategic plans. Most respondents pointed out that the management in the colleges ensured the necessary resources for the strategic plans are available and thus promoting the implementation process. When the management empowers the staff to enforce the policies the implementation of the strategic plans is enhanced as indicated by the respondents. The management style in the colleges selected is democratic in nature. According to Gupta (2008), the policies of the colleges concerning attainment of their goals are crucial and how well strategic plans are implemented depend on how the managers handle the implementation process. Rose and Kumar (2006) reported that organisation affects strategy implementation.

The study had also set out to establish the effects of colleges' culture on strategic plans. The research findings indicated that majority of the respondents were for the opinion that the colleges culture could lead to resistance due to the fear of the unknown in the colleges thus affecting the strategic plans implementation. Majority of the respondents were for the opinion that the colleges' culture in the various organizations inhibits the introduction of new strategic plans as reinforced by majority of the respondents. Other effects as identified by most respondents were that the colleges' culture places a gap of lack of procedures for implementing new plans and at times influence the support by other stake holders.

The research findings also indicated that the three indicator factors had effects on implementation of strategic plans. Of the three, organisation culture had the greatest impact, followed by management style and employees individual skills in that order. This means that much effort should be geared towards proper culture cultivation and change for successful strategic plan implementation.

\section{Conclusion}

The individual employee skills concerning the strategic plans, has an impact on the implementation process. The college that empowers its employees with skills to perform their duties could realise tremendous growth, performance and productivity. The management style of an institution has a significant impact on implementation of strategic planning. The management style in the colleges should ensure that the necessary resources and environment are available for strategic plans implementation. That the effects of colleges' culture on implementation of strategic plans are significant is evident. The institutions should develop a culture that embrace positive changes for tremendous improvement in the execution of its duties and hence accomplishment of the set objectives. The strengths of employees should be directed towards input for excellent performance in the areas of implementation of colleges' strategic plans.

\section{Acknowledgements}

The authors are grateful to Ministry of education official at Thika sub-county for availing data useful for identifying the institutions and determination of sampling size. The principals of the middle level colleges involved in this study are acknowledged for the permission to conduct the study in their institutions. The respondents who participated in this study are duly acknowledged for their time and willingness to provide the needed information.

\section{References}

Aalto University. (2000-2011). Strada: from Strategy into Action. Retrieved from http://www.strada.tkk.fi/in_english.html

Akhtar, S., Ding, D. Z., \& Ge, G. L. (2008). Strategic HRM practices and their impact on company performance in Chinese enterprises.Human Resource Management, 47(1), 15-32. http://dx.doi.org/10.1002/hrm.20195

Arthur, J. B. (1992). The Link between Business Strategy and Industrial Relations Systems in American Steel Minimills. Industrial and Labor Relations Review, 45(3), 488-506. http://dx.doi.org/10.2307/2524274

Bernardin, J. (2007). Human Resource Management: An Experiential Approach. New Delhi: McGraw Hill.

Block, P. (2007). The Empowered Manager: Positive Political Skills at Work. Jossey-Bass, San Francisco, CA: Corwin.

Borg, R.W., \& Gall, J. P. (2006).Educational Research. New York: Longman Publishers. 
Boxall, P., \& Purcell, J. (2000). Strategic human resource management: Where have we come from and where should we be going? International Journal of Management Reviews, 2(2), 183-203. http://dx.doi.org/10.1111/1468-2370.00037

Burnes, B. (2004). Kurt Lewin and the Planned Approach to Change: A Re-appraisal. Journal of Management Studies, 41(6). http://dx.doi.org/10.1111/j.1467-6486.2004-00463.x

Burnes, B. (2006). Organizational Choice and Organizational Change. England: Pearsons Education Limited. http://dx.doi.org//10.1108/00251749610150649

Carney, M. (2004).Middle manager involvement in strategy development in not - for - Profit organizations. The direction of nursing perspective-how organizational Structure impacts on the role. Journal of Nursing Management, 12, 13-21. htpp://dx.doi.org/10.1111/j.1365-2834.2004.00388.x

Cowling, A. (2009).Managing Human Resources (3rd ed.). Great Britain: Pearsons Education Limited.

Denison, D. R., \& Mishra, A. K. (1995). Toward a theory of organizational culture and effectiveness. Organization Science, 6(2), 204-223. http://dx.doi.org/10.1287/orsc.6.2.204

Drucker, P. F. (2005). Innovation and Entrepreneurship. London: Pan Publishers.

Fulford, M. (2005).The impact of empowerment on service employees. J. Managerial Issues, 7(2), 161-175.

Glueck, W. (2000). Strategic Management and Business Policy. New York: McGraw Hill.

Gupta, C. B. (2008). Human Resource Management. New Delhi: Education Publishers.

Hrebiniak, L. (2006). Obstacles to Effective Strategy Implementation. Organizational Dynamics, 35, 12-31.

Huse, E. F. (2000). Organizational Development and Change. Minneapolis: St Paul West Publishers.

Keuning, D. (2008). Management: A contemporary Approach. London: Pitman.

Kothari, C. R. (2004). Research methodology: Methods and techniques. New Delhi: New Age International Publishers.

Kotter, J.P., \& Hekett, J. L. (1992). Corporate culture and performance. New York: Free Press.

Mantere, S., \& Vaara, E. (2008). On the Problem of Participation in Strategy: A critical discursive perspective. Organization Science, 19(2), 341-358.

Mugenda, A. G. (2008). Social Science Research: Theory and Principles. Nairobi: Kijabe Printers.

Mugenda, O. M., \& Mugenda, A. G. (2003).Research Methods: Quantitative and Qualitative Approaches. Nairobi: ACT Press.

Odiek, B. A. (2010). Culture in Strategy Implementation.Nairobi: KIM Journal of Management.

Orodho, A. J. (2003). Essentials of Educational and Social Sciences Research Methods. Nairobi: Masola Publishers.

Pfeffer, J., \& Sutton, R. I. (2000). The Knowing-Doing Gap. Boston: Harvard Business School Press.

Rose, R. C., \& Kumar, N. (2006). The influence of organizational and human resource management strategies on performance. Performance Improvement, 45(4), 18-24. http://dx.doi.org/10.1002/pfi.2006.4930450406

Richard, Jr. P., \& Bagozzi, W. V. J. C. (2003). Culture Moderates the Self-Regulation of Shame and Its Effects on Performance. Journal of Applied Psychology, 88, 219-233. http://dx.doi.org/10.1037/0021-9010.88.2.219

Schein, E. H. (2010). Organizational Culture and Leadership. Jossey-Bass Business \& Management Series. San Francisco: Jossey-Bass.

Schuster, F. E. (2002). Human Resource Management: Concepts, Cases and Readings(2nd ed.). Virginia: Prentice Hall.

Shipton, H., Fay, D., West, M., Patterson, M., \& Birdi, K. (2005).Managing People to Promote $\begin{array}{llll}\text { Innovation.Creativity and Innovation } & \text { Management, 14(2), }\end{array}$ http://dx.doi.org10.1111/j.1467-8691.2005.00332.x

Whittington, R. (2007). Strategy Practice and Strategy Process: Family differences and the sociological eye. Organization Studies, 28, 1575-1586.

Wooldridge, B., Schmid, T., \& Floyd, S.W. (2008). The Middle Management Perspective on Strategy Process: Contributions, synthesis and future research. Journal of Management, 34, 1190. 
http://dx.doi.org/1177/0149206308324326

Wright, P. M., Gardner, T. M., Moynihan, L. M., \& Allen, M. R. (2005).The relationship between HR practices and firm performance: Examining the causal order. Personnel Psychology, 58(2), 409-446. http://dx.doi.org/10.1111/j.1744-6570.2005.00487.x

Yukl, G., \& Lepsinger, R. (2007).Getting It Done-Four Ways to Translate Strategy into Results. Leadership in Action, 27(2), 3-7.

\section{Copyrights}

Copyright for this article is retained by the author(s), with first publication rights granted to the journal.

This is an open-access article distributed under the terms and conditions of the Creative Commons Attribution license (http://creativecommons.org/licenses/by/3.0/). 